\title{
FinANCIAL DOLLARIZATION: EVAluATING THE CONSEQUenceS
}

\author{
Eduardo Levy-Yeyati ${ }^{1}$ \\ Universidad Torcuato Di Tella \\ Preliminary draft
}

April 2004

\begin{abstract}
Financial dollarization has been placed at the forefront of the policy debate in many developing economies, for reasons that include its influence on inflation performance and, most prominently, the currency imbalance and associated financial fragility that it introduces for the economy as a whole. This paper contributes to this debate by revisiting the evidence on the impact of FD on inflation, financial fragility and economic performance in light of a new updated database. It finds evidence that financially dollarized economies tend to display higher inflation rates, higher propensity to suffer banking crises and slower and more volatile output growth, without significant gains in terms of domestic financial depth.
\end{abstract}

\footnotetext{
${ }^{1}$ The author wishes to thank Gerardo Licandro, José Licandro, Eduardo Morón, Carmen Reinhart and participants at the XVIII Meeting of the IDB's Latin American Network of Central Banks and Finance Ministries, the 2003 Lacea Meetings and the IDB's Conference on Financial Dedollarization for their helpful comments, Ugo Panizza and Sergio Schmukler for their help with the data, Daniel Chodos and Cristina Azea for outstanding research assistance and, especially, Eduardo Fernández Arias for his decisive encouragement and invaluable suggestions. Financial support from the Inter-American Development Bank is gatefully acknowledged.
} 


\section{Introduction}

As defined in Ize and Levy Yeyati (2003), financial dollarization simply denotes an empirical observation: the holding by residents of foreign currency-denominated assets and liabilities, including bank deposits and loans as well as non-bank assets such as commercial paper or sovereign debt. ${ }^{2}$ The descriptive nature of this definition implicitly recognizes that the presence of FD is merely a symptom of a weak currency problem (namely, the rejection of the local currency as store value) for which the literature has already advanced and tested a number of alternative explanations. ${ }^{3}$

However, regardless of the underlying causes, the presence of financial dollarization has been increasingly seen both in academic and policy circles as a source of concern due to its potential implications in terms of monetary instability, financial fragility and overall economic performance. The purpose of this paper is to evaluate empirically whether and to what extent these implications are verified in the data.

There are many reasons why financial dollarization has been placed at the forefront of the policy debate. First, inasmuch as financial dollarization influences the pricing behavior of firms and individuals, dollarized economies are induced to limit wide fluctuations in the nominal exchange rate due to their deleterious impact on inflation performance. As Chang and Velasco (2000) point out, "any scheme to control the rate of inflation at a short horizon must control, to some extent, the nominal exchange rate." Moreover, financially dollarized economies may exhibit a more elastic price response to monetary shocks as onshore dollar assets are more readily available as a safe haven against inflation.

More recently, the financial dollarization debate has centered around the incidence of the associated currency mismatch. In this regard, while some dollarization may be required by producers of tradables as a hedge against exchange rate risk, widespread financial dollarization inevitably introduces a currency mismatch for the economy as a whole (either at the domestic banks' balance sheets through local currency on-lending of foreign currency funds, or through real exchange rate exposure of dollar borrowers with income largely denominated in non-tradables as in the case of most local producers or the public sector). This mismatch, and the resulting real exchange rate exposure, amplifies the impact of real shocks through its negative effect

\footnotetext{
${ }^{2}$ In what follows, following what has become standard in the dollarization literature, dollar and foreign currency, and peso and local currency are used interchangeably.

${ }^{3}$ Existing explanations point at portfolio hedging considerations (Ize and Levy Yeyati, 2003), time inconsistency problems related to the temptation to dillute local currency obligations through inflation (Calvo and Guidotti, 1989), the incidence of implicit debtor guarantees (Burnside et al., 2001), currency-blind financial regulation (Broda and Levy Yeyati, 2003) and signaling problems (De la Torre et al., 2003), among others. See De Nicoló et al. (2003) and Levy Yeyati (2003) for a discussion and empirical testing of some of these hypotheses.
} 
on debtors' balance sheets, possibly leading to financial fragility, a concern that has been flagged by most of the recent currency and financial crises. ${ }^{4}$

On the other hand, inasmuch as this currency imbalance and the associated sensitivity to large real devaluations conditions the willingness of the monetary authorities to use the exchange rate as a shock absorber, ${ }^{5}$ the authorities' unwillingness to let the real exchange rate fluctuate may feed back into financial dollarization, as dollar debtors anticipate either a stable real exchange rate or, if this strategy becomes unsustainable, a government bail out. ${ }^{6}$ Finally, this RER exposure may explain the procyclical pattern of international capital flows to developing economies, as negative real shocks that tend to depreciate the local currency increase the leverage ratio of debtors in a financially dollarized country amplifying the effect of the cycle on the debtor's capacity to pay. ${ }^{7}$

The vast body of analytical literature on financial dollarization and currency mismatches spurred by the recent episodes of financial distress contrasts with the scarcity of empirical work to support or refute the concerns previously discussed. ${ }^{8}$ To contribute to fill this gap, this papers exploits an comprehensive database on alternative sources of financial dollarization to examine its impact on monetary stability, financial fragility and economic performance.

The definition and measurement of financial dollarization used in this paper already entails taking sides on an issue that is certainly far from settled issue, as witnesses the discussion in Eichengreen et al. (2003), and Goldstein (2003). In particular, part of the literature on currency mismatches have focused on the country's foreign currency indebtedness vis a vis non-residents, in the view that foreign assets and liabilities held domestically should cancel each other out, with no impact on economic performance. This focus, however, suffers from at least two important shortcomings. First, markets and holder residence tend to overlap, making the

\footnotetext{
${ }^{4}$ See, among others, Krugman (1999), Aghion et al. (2000) and Céspedes et al. (2002). De la Torre et al. discuss the crucial role played by impending balance sheet effects in the recent Argentine crisis.

${ }^{5}$ This argument has been proposed by Calvo and Reinhart (2002), among others, to account for "fear of floating," that is, the tendency to avoid substantial exchange rate volatility through foreign exchange intervention under formally floating exchange rate regimes. In line with this hypothesis, Levy Yeyati and Sturzenegger (2003) find that financially dollarized countries tend to adopt de facto a more rigid exchange rate regime. It has to be noted, however, that if prices are nominally flexible, the real exchange rate adjustment to external shocks should materialize through deflation over a longer period of time, to the same qualitative effect. Empirical evidence on a deflationary adjustment under a peg is presented in Galiani et al. (2003).

${ }^{6}$ See Burnside et al. (2001). Indeed, this implicit guarantee has been at least partially validated in many recent crises (Mexico 1994 and Brazil 1998). Certainly, the forcible pesification of debts in Argentina after the collapse of the currency board agreement was an extreme case in which these beliefs were expost fully confirmed.

${ }^{7}$ By contrast, in non-dollarized economies, the adjustment to a more depreciated equilibrium RER that comes through nominal depreciation typically improves (via debt dilution) the debtor's capacity to pay relative.

${ }^{8}$ Exceptions include De Nicoló et al. (2003), Arteta (2002), and Calvo et al. (2003).
} 
distinction between residents and foreigners almost impossible to trace given the available data, particularly for those developing economies for which financial dollarization represents a potential concern.

More importantly, even if the required data were available, the aggregation argument does not tend to materialize in practice. While a financially dollarized economy may be currency-balanced as a whole, it will likely be imbalanced at a micro level, as resident holders of financial assets typically differ from foreign currency debtors. In turn, at the time of a real exchange rate adjustment, individual mismatches, rather than netting out, tend to lead to capital flight, bank runs, massive bankruptcies and endless litigation even in the absence of net external position vis a vis non residents. $^{9}$

Finally, there is mounting evidence that the overall degree of financial dollarization may be influenced by a home currency bias by which the currency composition of residents and non-residents differs, with the former more prone to invest in local currency assets than the latter. ${ }^{10}$ As a result, it suggests that the overall currency mismatch, to the extent that it is correlated with the dependence on foreign borrowing, is associated with the inability to induce residents to hold local currency assets. The definition of financial dollarization used here explicitly embraces this home bias view. ${ }^{11}$

The route map of the paper is the following. Section II addresses the measurement problem, and presents an overview of levels and trends of alternative measures of FD in recent years. Section III reports the empirical tests of the consequences of financial dollarization. Finally, Section IV summarizes the main policy implications and concludes.

\footnotetext{
${ }^{9}$ Indeed, even in those cases in which individual debtors are currency hedged, it is easy to conceive the case in which they file for bankruptcy after diverting their foreign currency assets right before the currency collapse. Following standard conventions, by external I refer to an obligation issued under international (as opposed to domestic) Law. Thus, debt issued under New York Law would be domestic if the issuer is a U.S. resident and external otherwise, irrespective of the nationality of the holder.

${ }^{10}$ The point is made analytically Thomas (1983) and Ize and Levy Yeyati (2003). Bordo et al. (2002) discusses it from a historical perspective. In a related paper, Claessens et al. (2003) find that the dollarization ratio of (internal plus external) government bonds is negatively related with the size of the domestic financial market.

${ }^{11}$ This contrasts with the related literature on "original sin," which denotes the inability to borrow in domestic currency internationally (see Eichengreen et al., 2003, and references therein). It has to be noted, though, that there is no prima facie evidence supporting the view that original sin reflects inability to issue local currency bonds (as opposed to unwillingness to incur the cost of a high currency premia).
} 


\section{FD in the data}

Measurement is certainly a non-trivial aspect in the financial dollarization debate, at least for two reasons. Firstly, the particular issue under study would tend to favor one particular aspect of dollarization (and, in turn, one particular measure) over the others. Thus, while the impact of financial dollarization on monetary stability requires a good measure of the dollar share of residents' savings (for example, the deposit dollarization ratio), the influence of dollarization on financial fragility and crisis propensity calls for a measure of the liability dollarization ratio of domestic financial institutions. Finally, the impact on output volatility and growth, inasmuch as it is related to the real exchange rate exposure of the economy as a whole, is more likely to depend on total (internal and external, private and public) dollar indebtedness.

Secondly, the choice of a measure depends crucially on data availability, in terms of both country and period coverage. A substantial amount of data is already available on the currency composition of domestic deposits, and the latter can be used as a reasonable proxy for domestic loan dollarization, as they often mirror each other due to the presence of prudential limits on banks' foreign exchange positions (Figure 1). The same is valid for dollarized official credit and, to varying degrees, to crossborder deposits and loans (possibly biased downward due to underreporting) and external bonded debt. On the other extreme, data on the dollar share of domestic debt is rather difficult to produce. ${ }^{12}$

In light of the aforementioned constraints, and in order to maximize sample size, in the following empirical exercises I will focus primarily on the onshore deposit dollarization ratio as the main dollarization measure. The deposit dollarization series used here is constructed by assembling data reported in De Nicoló et al. (2003), Arteta (2002), Baliño et al. (1998), various central bank bulletins and IMF Article IV Staff Reports. As a result, the final series covers over 1524 observations for 122 developed and developing countries over the period 1975-2002. ${ }^{13}$

Table 1.a provides a quick glance at the order of magnitude of the deposit dollarization levels and trends. As the table indicates, the average dollar share of domestic deposits increased from 20\% in 1990 to $30 \%$ in 2001. Comparable trends are

\footnotetext{
${ }^{12}$ Reinhart et al. (2003) construct a dollarization index based on the dollarization ratios of domestic deposits, external debt and domestic public debt. However, as they state in the appendix, available data on the latter covers only 24 countries. Classens et al. (2003), computing the dollarization of government debt from BIS sources, assume that all domestic debt is denominated in local currency (with the exception of Argentina for which they have an alternative source) anbstracting from the fact that governments in many financially dollarized countries issue domestic dollar (or dollar-linked) debt.

${ }^{13}$ Data reported in those sources has been cheked for consistency and, in many casse, revised accordingly. For testing purposes, I exclude de jure dollarized economies, in line with the view that micro mismatches are as important, if not more important than aggregate mismatches. Table A1 in the Appendix presents a list of countries and periods covered. A list of variable definitions and sources is presented in Table A2. For ease of comparison, Table 1 was prepared over a consistent sample of countries for which GDP and inflation data are available for the whole period.
} 
apparent for transition and Latin American economies where financial dollarization has been particularly pervasive. ${ }^{14}$ As has been already well documented in the literature, deposit dollarization in emerging economies grew or remained relatively stable in most developing countries despite a marked decline in inflation rates across the board during the last decade.

Table 1.b. illustrates the relative importance of deposit dollarization, normalized by the country's GDP as a way of capturing the associated currency exposure, by comparing it with other alternative sources of financial dollarization: i) official (bilateral and multilateral) lending, ii) cross-border bank loans to local residents, and iii) external (private and public) bonded debt. ${ }^{15}$ The sample includes developing countries for which data on all sources are available, and excludes offshore financial centers, where financial dollarization is typically large and of a different nature that the one studied here.

As noted, the use of onshore deposit dollarization is a natural way to test the impact on monetary policy and, to the extent that it proxies onshore loan dollarization, to assess the consequences in terms of financial fragility. However, alternative measures of financial dollarization will be used as a robustness check in those cases in which that are likely to play a crucial role.

\section{Evaluating the consequences}

\section{Dollarization and monetary policy}

The earlier literature stressed the fact that dollarization, by reducing the costs of switching to the foreign currency to avoid the effects of inflation, may increase the volatility of money demand impinging in the capacity of the central bank to conduct monetary policy. While this concern was rooted in the view of dollarization as a currency substitution phenomenon, a similar argument could be made regarding the dollarization of domestic savings. Specifically, as the flight to readily available foreign-currency assets becomes less costly, the demand for reserve money should be more sensitive to monetary expansions in a dollarized economy. On the positive side, financial dollarization may reduce the temptation to inflate and be conducive, ceteris

\footnotetext{
${ }^{14}$ Dollarization ratios in transition economies are computed over a shorter period. As a result of the associated real exchange rate appreciation that followed price liberalization in these countries, initial ratios may overstate the long run dollarization levels. On the impact of the real exchange rate variations on dollarization ratios, see Baliño et al. (1999).

${ }^{15}$ The data is from the Bank of International Settlements, with exception of official credit, sourced from the World Bank's GDF. While no information on the currency of denomination of cross-border deposits and loans is provided, it is reasonable to assume, as I do here, that in the case of developing economies they are foreign denominated. Appendix B presents tables with country and period coverage for all dollarization series. Appendix $\mathrm{C}$ reports a list of variable definition and sources used in the paper.
} 
paribus, to lower inflation expectations, as it increases the perceived cost of monetary expansions both in terms of inflation and due to balance sheet concerns.

To address these hypotheses, I test a simple specification based on the log linearization of a standard money demand equation. Specifically, I regress the log difference of the consumer price on the log differences in broad money (M2) and real GDP, and the change in the nominal interest rate, plus three regional dummies corresponding to Latin American (latam), sub-Saharan African (safrica) and transition economies (trans), and year dummies. ${ }^{16}$ To this I add the deposit dollarization ratio and its interaction with money growth. If financial dollarization induce lower inflation expectations, the total effect of deposit dollarization should be negative. In turn, a greater sensitivity of inflation to money growth should be captured by a positive interaction coefficient.

Overall, the results in Table 3 confirm our priors, indicating that dollarization has a beneficial short-run effect on inflation through a sobering effect on expectations, at the expense of a greater sensitivity of inflation to changes in the monetary aggregate. The first columns presents the baseline specification, controlling for country-specific effects. The coefficients display the correct sign (positive for money growth and interest rates, negative for output growth). Column (2) shows an OLS regression on the average dollarization ratio and its interaction with money. ${ }^{17}$ The dollarization coefficient has the expected negative sign (more dollarization leading to less inflation), although it is not significant. On the other hand, the interaction reveals that onshore dollarization raises significantly the elasticity of inflation with respect to money growth. As an indicative example, a 100\% deposit dollarization level implies that the coefficient on money creation nearly doubles. Comparable results are obtained using country-specific effects (column 3). The coefficient on deposit dollarization becomes significant when we replicate the previous two regressions using the current dollarization ratio instead of its average (columns 4 and 5). Reassuringly, the rest of the coefficients are virtually unchanged.

The implications of these two offsetting effects (namely, a lower inflation bias countervailing a higher inflation sensitivity) for long-run inflation rate are not straightforward. To address this question, we run a cross-section regression of average inflation on the average GDP and money growth rates and the average dollarization level (column 6). The coefficient shows up positive but not significant. A positive link between dollarization and inflation, however, presents obvious endogeneity concerns (as higher inflation may lead to higher deposit dollarization). To mitigate this problems, we instrument dollarization using an index of the degree of restrictions to onshore dollarization, in place as of 2000 (restrictions), constructed following De

\footnotetext{
${ }^{16}$ The inclusion of additional variables such as openness, government consumption or exchange rate regimes yield similar results at the cost of a loss of observations, and are thus ommited. Results are available upon request.

${ }^{17}$ Regional dummies are also introduced and display the expected positive sign.
} 
Nicoló et al. (2003). ${ }^{18}$ The results show a positive and significant association between dollarization and inflation, suggesting that the short-run effect in terms of inflation expectations is ultimately offset by the incidence of a more sensitive inflation response.

\section{Dollarization and financial fragility}

Perhaps the concern more frequently emphasized in relation to financial dollarization is its deleterious impact on financial fragility. Recent work have reported some supporting evidence. On the one hand, De Nicoló et al. (2003) find that dollarized banking sectors exhibit higher risk profiles (as measured by the Z-index, a proxy of distance to default) ${ }^{19}$ and deposit volatility (in line with the greater volatility of money demand revealed in the previous section). Calvo et al. (2003), in related work, document that the propensity to suffer sudden stops in capital inflows (possibly an important trigger of financial crises) increases with the degree of financial dollarization (defined as BIS reporting banks' local asset positions in foreign currency as a share of GDP).

Closer to the focus of this paper, Domac and Martínez Pería (2000) find the foreign liabilities to assets ratio of local banks to be positively correlated with the probability of a systemic banking crisis. This is at odds, however, with Arteta (2003), who find, for a somewhat smaller sample, little evidence that onshore financial dollarization raises the probability of facing a banking crisis. Thus, it appears that one the main themes of the financial dollarization debate, namely its presumed incidence on financial fragility and crisis propensity due to the presence of balance sheet effects, it still to be validated by the evidence.

I revisit this issue by modeling the probability of facing a banking crisis as a function of standard crisis determinants (lagged to limit potential endogeneity problems), the change in the nominal exchange rate in the previous period, and two financial dollarization measures: a deposit dollarization dummy (which equals 1 whenever the deposit dollarization ratio for the previous year exceeds $10 \%$ ), and the ratio between local banks' foreign currency liabilities and assets, to capture nondeposit liability dollarization of local banks.

\footnotetext{
${ }^{18}$ While the index of restrictions corresponds to the year 2000, it can be reasonably assumed that the degree of restrictiveness in individual countries is relatively constant over time. Indeed, the index exhibits a high and statistically significant correlation with annual dollarization ratios in different years. On the other hand, it is not correlated with inflation in any of the specifications in the table. The index, based on the IMF's AREAER, is reported in Appendix B. See De Nicoló et al. (2003) for a description. ${ }^{19}$ More precisely, the index measures the probability that a loss (negative ROA) exceeds the bank's equity capital $(E Q)$ or

$$
P\left(R O A \leq-\frac{E Q}{A}\right) \leq \frac{\sigma_{R O A}^{2}}{\left(\mu_{R O A}+\frac{E Q}{A}\right)^{2}} \equiv \frac{1}{Z^{2}}
$$
}

Thus, a smaller $\mathrm{Z}$ would indicate a larger risk exposure. 
Specifically, I use as dependent variable a dummy that equals one for the first period of the crisis, and zero in non-crisis periods. Crisis periods following the first one are dropped from the sample to abstract from any impact that the crisis may have on the explanatory variables. In turn, the set of standard controls comprises the inflation rate, changes in the terms of trade, the real interest rate, the real GDP growth rate, and the ratios of M2 to international reserves, private credit to GDP, liquid to total assets, and capital flows to GDP. In addition, I add the real GDP per capita as a broad control for institutional quality. Finally, to test whether financial dollarization increases the propensity of a crisis for a given exchange rate adjustment, some regressions include the interaction of the change in the exchange rate with the financial dollarization measures.

The results are reported in Table 5. The first column includes only the standard regressors. All display the expected sign although only a few are statistically significant at conventional levels, possibly due to multicolinearity problems. Column 2 introduces the change in the exchange rate and the dollarization variables, which show a positive and, in the case of the latter, significant effect on crisis propensity. Finally, column 3 adds the interaction terms. As can be seen, both interactions are positive and significant, indicating that onshore dollarization increases the incidence of exchange rate changes in the probability of suffering a banking crisis. The total effect of each dollarization measure, positive and significant as expected, are reported at the bottom.

As the table shows, the number of observations is reduced substantially when al regressors are included. To check whether the results are sensitive to the small sample covered in columns 2 and 3, columns 4 and 5 simply replicate these tests using a subsample of the set of standard controls. The qualitative results are not altered. Interestingly, in both cases, the total effect of an exchange rate change is not significant once the dollarization variables are included, suggesting that an exchange rate shock appears to have a negative impact only through its balance sheet effect. ${ }^{20}$

The previous results substantiate the concern linking financial dollarization with financial fragility through the balance sheet channel. Dollarization advocates, however, has often stressed that this undesired consequence should be weighted against the beneficial effects of onshore dollarization on local intermediation, in countries where financial markets would otherwise be insufficiently developed due to a weak currency problem. A final answer to the question about whether financial dollarization helps develop domestic markets in weak currency economies remains elusive, as empirical testing is mined by the scarcity of data and the difficulty to

\footnotetext{
${ }^{20}$ In fact, its sign turns negative, suggesting that banking sectors in non-dollarized economies actually may benefit from an exchange rate adjustment, possibly due to its positive impact on the real economy. Unfortunately, the coefficients are not significant and more testing is needed to assess whether this positive effect is actually in place.
} 
control for all relevant factors that may influence both currency denomination and financial development.

However, a recent study by De Nicoló et al. (2003) provides some valuable preliminary insights. By regressing financial depth (measured as the M2 to GDP ratio) on the deposit dollarization ratio plus a number of additional controls, they find that dollarization is not associated per se with deeper markets, except in high inflation countries where it appears to have a countervailing effect. ${ }^{21}$ In addition, it shows that the imposition of restrictions on onshore dollarization has no effect on the degree of financial depth, which suggest that the desintermediation effects of limiting dollarization de jure may have been overstated in the debate.

A cursory look at the data seems to reveal a negative dollarization-financial depth link, as shown in Figure 2, where I plotted average M2-to-GDP and dollarization ratios. Offshore centers are singled out in the figure by a square marker. As can be seen, three of them are clear outliers relative to what appears to be a significant negative association. Once offshore centers are excluded from the sample, a simple regression of financial depth on deposit dollarization yields a significant and negative correlation.

In sum, while concerns related to financial fragility seem to be supported by the evidence, there seems to be little empirical ground for the foregone conclusion that dollarized countries are compensated with the benefit of more liquid domestic financial markets.

\section{Dollarization and growth}

Although the final test of the net effect of financial dollarization lies in its implication for growth and output volatility, there are surprisingly few empirical studies that systematically addresses this issue. ${ }^{22}$ Regarding output volatility, the increased real exchange exposure typically associated with dollarization would indicate that dollarized countries are likely to exhibit greater output variability. Moreover, one could argue that, because they are known to be more sensitive to currency fluctuations, dollarized countries are bound to be the subject of speculative attacks, endogenizing to some extent the distribution of external shocks. ${ }^{23}$

Less straightforward is the case for long-run growth. While output volatility may have adverse consequences for growth (Ramsey and Ramsey, 1995),

\footnotetext{
${ }^{21}$ Similar results are based using the present database.

${ }^{22}$ The only exception is, perhaps, Reinhart et al. (2003) where they compare average growth performance as a function of different measures of dollarization, with mixed results.

${ }^{23}$ This hypothesis can be thought of an extension Calvo's (1999) claim that pegs are likely to suffer more volatile external shocks due to speculative attacks, to the case of a dollarized economy where the government is expected to mitigate the depreciation of the local currency at the cost of a loss of reserves.
} 
dollarization, by deepening financial markets, may fuel investment offsetting the previous effect. However, as we have seen, the alleged financial impact does not show in the data, tilting the balance against dollarization.

A cursory look at the data yields interesting preliminary insights. Table 7a reports the means test of the two variables of interest (growth and growth volatility) for high a low dollarization countries, defined as those with average dollar ratios above or below the sample median. As can be seen, the latter display significantly faster and more stable growth than the former. Similar conclusions can be drawn from the correlations in Table 7b. Thus, a bird's eye look at the data appears to indicate that dollarization does have negative implications for growth.

This is consistent with the results of the cross-section regressions of Tables 7cd. The first table reports growth regressions of average growth on the average dollarization ratio and standard controls such as initial per capita GDP, initial human capital (proxied by the ration of secondary school enrollment at the beginning of the period, sec), plus the averages of the investment-to-GDP ratio, the population growth, and regional dummies. The table indicates that dollarization is negatively associated with growth, and significantly so when offshore economies are excluded. Instrumenting dollarization with restrictions reinforces the results. The results concerning output volatility are even more robust (Table 7d). Dollarization is significantly related with volatility, even after controlling for terms of trade and nominal exchange rate volatility (column 4) and excluding offshore financial centers (column 5).

The literature on the real consequences of financial dollarization has emphasized the incidence of the aggregate currency mismatch, focusing on external foreign currency liabilities. While this does not deny the relevance of onshore dollarization as a source of financial distress, offshore dollarization certainly played a role in recent financial crises and helps explain the deleterious effects of exchange rate adjustments on economies where onshore dollarization is virtually null. More generally, we would expect to observe a negative link between measures of offshore dollarization and output volatility, particularly in developing economies. This link is explored in the last three columns in Table 7, where we replicate the previous tests using the ratio of foreign bonded debt (private and public) over GDP as a proxy for the external mismatch. As can be seen, output volatility appears to be positively and significantly correlated with the level of foreign currency bonded debt for nonindustrial economies (but not for industrial ones), even after controlling for nominal instability over the period (proxied by average inflation) and the degree of openness. ${ }^{24}$

These findings suggest that dollarization (both domestic and external) may have a detrimental effect on the real economy. While a more careful exploration of these links that takes into account potential simultaneity problems is warranted, this 
preliminary exploration support the view that, for a dollarized developing economy, the growth path is likely to be slower and choppier than for the rest.

\section{Final remarks}

The previous section showed that financially dollarized economies tend to display a greater sensitivity of domestic prices to money creation and higher inflation rates (contradicting the view of dollarization as a self-disciplining device), a greater propensity to suffer systemic banking crises, and slower and more volatile output growth, without any visible gain in terms of financial depth. In sum, the evidence confirmed some of the concerns typically associated with financial dollarization, and cast doubt on certain arguments that have been used in its favor.

Overall, these findings provide a case for promoting dedollarization as an active policy. Both the previous evidence and the lessons from past and current dedollarization experiences suggest that any such strategy should entail a two-way approach. $^{25}$ On the one hand, short of a quantitative limit on onshore dollar intermediation (as is the case in many developed and emerging economies), prudential regulation should be revised to address ex-ante the factors that favor the use of the dollar, as is gradually being done, rather belatedly, by some financially dollarized economies such as Argentina and Uruguay after recent systemic financial crises. ${ }^{26}$ On the other, pari passu with this revisions, peso instruments should be the introduced and promoted to limit the impact of more stringent regulation in terms of domestic financial intermediation, either through the use of indexation as in Chile or more naturally through the development of local currency markets for government debt as a substitute for foreign currency-denominated external obligations, as has been done, for example, in Mexico after the Tequila crisis.

Needless to say, any successful dedollarization strategy should be accompanied by sound and credible monetary and fiscal policies. However, as witness the Argentine convertibility, the Uruguayan crawling peg or the Peruvian managed float, sound monetary policies are necessary but may not be sufficient. A proactive agenda with specific measures aimed at mitigating the presence of externalities and enhancing the attractiveness of local currency assets may be needed to complement conducive macro policies. Ultimately, the economic implications of financial dollarization appear to justify the effort.

\footnotetext{
${ }^{25}$ See Levy Yeyati (2003) for a detailed discussion along these lines.

${ }^{26}$ Measures along these lines include, for example, equalizing the local currency coverage of deposit insurance across currencies or factoring in the currency exposure of debtors in the computation of provisions and risk-based capital requirements.
} 


\section{REFERENCES}

Arteta, Carlos (2002). Exchange rate regimes and financial dollarization: Does Flexibility Reduce Bank Currency Mismatches? International Finance Discussion Papers 738, Board of Governors of the Federal Reserve System (U.S.)

Baliño, Tomás, Adam Bennet, and Eduardo Borensztein (1999). "Monetary Policy in Dollarized Economies," IMF Occasional Paper 171.

Bordo, Michael, Christopher Meissner and Angela Redish (2002). How "Original Sin” was Overcome: The Evolution of External Debt Denominated in Domestic Currencies in the United States and the British Dominions 1800-2000. Mimeo.

Broda, Christian and Eduardo Levy-Yeyati (2003). Endogenous Deposit Dollarization. Federal Reserve Bank of New York Staff Papers, No. 160.

Burnside, Craig, Martin Eichenbaum, Sergio Rebelo, (2001). Hedging and Financial Fragility in Fixed Exchange Rate Regimes. European Economic Review 45 (7).

Calvo, Guillermo and Pablo Guidotti (1989). Credibility and nominal debt: exploring the role of maturity in managing inflation. IMF Working Paper 89/73.

Calvo, Guillermo and Carmen Reinhart (2002). Fear of Floating. Quarterly Journal of Economics 117 (2).

Chang, Roberto and Andrés Velasco (2000). Exchange Rate Policy for Developing Countries. American Economic Review 90.

Claessens, Stijn, Daniela Klingebiel and Sergio Schmukler (2003). "Government Bonds in Domestic and Foreign Currency: The Role of Macroeconomics and Institutional Factors." Mimeo, The World Bank.

De la Torre, Augusto, Eduardo Levy-Yeyati and Sergio Schmukler (2003). Beyond the Bipolar View: The Rise and Fall of Argentina's Currency Broad. Economía, forthcoming.

De Nicoló, Gianni, Patrick Honohan, and Alain Ize (2003). Dollarization of the Banking System: Good or Bad? Mimeo, IMF.

Domak, Ilker and María Soledad Martínez Pería (2000). Banking Crises and Exchange Rate Regimes: Is There a Link? Mimeo, The World Bank.

Eichengreen, Barry, Ricardo Hausmann, and Ugo Panizza (2003). Currency Mismatches, Debt Intolerance and Original Sin: Why They are Not the Same and Why it Matters, NBER Working Paper No. 
Galiani, Sebastián, Eduardo Levy-Yeyati, and Ernesto Schargrodsky (2003). Financial Dollarization and Debt Deflation under a Currency Board, Emerging Markets Review. Garcia, Gillian (1999). Deposit Insurance - A Survey of Actual and Best Practices. IMF WP/99/54.

Guidotti, Pablo and Carlos Rodriguez (1992). Dollarization in Latin America: Gresham's Law in Reverse? IMF Staff Papers, Vol. 39.

Levy-Yeyati, Eduardo (2003). Financial Dollarization: Where Do We Stand? Mimeo, IDB.

Ize, Alain and Eduardo Levy-Yeyati (2003). Financial Dollarization. Journal of International Economics, 59.

Levy-Yeyati, Eduardo and Federico Sturzenegger (2003). On the Endogeneity of Exchange Rate Regimes. Mimeo, Universidad Torcuato Di Tella.

Reinhart, Carmen, Kenneth Rogoff and Miguel Savastano (2003). Addicted to Dollars. NBER Working Paper No.

Thomas, L.R. (1985). Portfolio Theory and Currency Substitution. Journal of Money, Credit, and Banking, Vol. 17. 
Table 1a. Deposit Dollarization and Inflation

\begin{tabular}{lccccccc}
\hline & & \multirow{2}{*}{ Dollarization } & \multirow{2}{*}{ Inflation } & \multicolumn{2}{c}{ Latam } & \multicolumn{2}{c}{ Transition } \\
\cline { 5 - 8 } & & & & Dollarization & Inflation & Dollarization & Inflation \\
\hline \multirow{2}{*}{1990} & mean & 20.5 & 45.4 & 21.1 & 71.0 & $35.8^{*}$ & $30.5^{*}$ \\
& median & 15.6 & 15.0 & 13.3 & 17.4 & 30.0 & 24.8 \\
Obs. & & 45 & 45 & 21 & 21 & 12 & 12 \\
\hline \multirow{2}{*}{2001} & mean & 30.4 & 8.9 & 28.9 & 5.0 & 47.7 & 7.2 \\
& median & 20.1 & 4.0 & 18.9 & 4.0 & 48.0 & 7.1 \\
Obs. & & 71 & 71 & 22 & 22 & 15 & 15 \\
\hline
\end{tabular}

*For transition economies we use 1995 data.

Table 1b. Dollar liabilities over GDP: Alternative Sources (non-industrial counteies excluding offshore financial centers)

\begin{tabular}{lcccccc}
\hline & & $\begin{array}{c}\text { Domestic } \\
\text { deposits }\end{array}$ & $\begin{array}{c}\text { Cross-border } \\
\text { loans }\end{array}$ & $\begin{array}{c}\text { External } \\
\text { bonded debt }\end{array}$ & $\begin{array}{c}\text { Official long- } \\
\text { term debt }\end{array}$ & Total $^{*}$ \\
\hline \multirow{2}{*}{1995} & mean & 6.98 & 14.55 & 3.74 & 16.51 & 41.80 \\
& median & 5.56 & 11.39 & 1.79 & 11.81 & 39.82 \\
Obs. & & 26 & 26 & 26 & 26 & 26 \\
$\min$ & & 0 & 2.46 & 0.16 & 0 & 11.97 \\
$\max$ & & 25.53 & 53.81 & 35.02 & 75.80 & 111.42 \\
\hline \multirow{2}{*}{2000} & mean & 9.93 & 12.62 & 8.28 & 13.051 & 43.88 \\
& median & 8.41 & 10.90 & 6.44 & 11.11 & 41.31 \\
Obs. & & 29 & 29 & 29 & 29 & 29 \\
$\min$ & & 0.01 & 2.72 & 0.57 & 0 & 17.26 \\
$\max$ & & 37.61 & 25.44 & 25.75 & 41.56 & 80.64 \\
\hline
\end{tabular}

* Sum of the GDP ratios of dollarization of domestic deposits, cross border loans, external bonded debt, and official credit.

Note: Excludes outliers: Guyana, Nicaragua and Sao Tome \& Principe. 
Table 2. Dollarization and Inflation

Dependent Variable: $\Delta p$

\begin{tabular}{|c|c|c|c|c|c|c|c|}
\hline & $\begin{array}{l}\text { FE } \\
(1)\end{array}$ & $\begin{array}{l}\text { OLS } \\
(2)\end{array}$ & $\begin{array}{l}\mathrm{FE} \\
(3)\end{array}$ & $\begin{array}{l}\text { OLS } \\
(4)\end{array}$ & $\begin{array}{l}\text { FE } \\
(5)\end{array}$ & $\begin{array}{l}\text { Avg } \\
(6)\end{array}$ & $\begin{array}{c}\operatorname{Avg}(i) \\
(7)\end{array}$ \\
\hline$\Delta \mathrm{m}$ & $\begin{array}{c}0.841 * * * \\
(0.065)\end{array}$ & $\begin{array}{c}0.676^{* * *} \\
(0.087)\end{array}$ & $\begin{array}{c}0.515 * * * \\
(0.119)\end{array}$ & $\begin{array}{c}0.703 * * * \\
(0.132)\end{array}$ & $\begin{array}{c}0.579 * * * \\
(0.150)\end{array}$ & & \\
\hline$\Delta \operatorname{lgdp}$ & $\begin{array}{c}-0.448 * * * \\
(0.114)\end{array}$ & $\begin{array}{c}-0.698 * * * \\
(0.129)\end{array}$ & $\begin{array}{c}-0.597 * * * \\
(0.132)\end{array}$ & $\begin{array}{c}-0.627 * * * \\
(0.199)\end{array}$ & $\begin{array}{c}-0.502 * * \\
(0.202)\end{array}$ & & \\
\hline$\Delta$ intrate & $\begin{array}{c}0.000 * * * \\
(0.000)\end{array}$ & $\begin{array}{c}0.000 * * * \\
(0.000)\end{array}$ & $\begin{array}{c}0.000 * * * \\
(0.000)\end{array}$ & $\begin{array}{c}0.000 * * * \\
(0.000)\end{array}$ & $\begin{array}{c}0.000 * * * \\
(0.000)\end{array}$ & & \\
\hline latam & $\begin{array}{c}0.000 \\
(0.000)\end{array}$ & $\begin{array}{l}0.025^{*} \\
(0.013)\end{array}$ & & $\begin{array}{c}0.015 \\
(0.013)\end{array}$ & & $\begin{array}{c}0.021 \\
(0.016)\end{array}$ & $\begin{array}{c}0.025 \\
(0.019)\end{array}$ \\
\hline safrica & $\begin{array}{c}0.000 \\
(0.000)\end{array}$ & $\begin{array}{c}0.045 * * * \\
(0.011)\end{array}$ & & $\begin{array}{l}0.046^{*} \\
(0.027)\end{array}$ & & $\begin{array}{c}0.054 * * \\
(0.024)\end{array}$ & $\begin{array}{c}0.057 * * \\
(0.025)\end{array}$ \\
\hline transition & $\begin{array}{c}0.000 \\
(0.000)\end{array}$ & $\begin{array}{c}0.075 * * * \\
(0.022)\end{array}$ & & $\begin{array}{c}0.060^{* *} \\
(0.023)\end{array}$ & & $\begin{array}{c}0.076 \\
(0.054)\end{array}$ & $\begin{array}{c}0.056 \\
(0.057)\end{array}$ \\
\hline dollar_avg & & $\begin{array}{l}-0.086 \\
(0.052)\end{array}$ & & & & $\begin{array}{c}0.081 \\
(0.079)\end{array}$ & $\begin{array}{c}0.190 * * \\
(0.094)\end{array}$ \\
\hline$\Delta \mathrm{m}$ _dollar_avg & & $\begin{array}{c}0.599 * * * \\
(0.202)\end{array}$ & $\begin{array}{c}0.899 * * * \\
(0.282)\end{array}$ & & & & \\
\hline dollar & & & & $\begin{array}{c}-0.161 * * \\
(0.076)\end{array}$ & $\begin{array}{c}-0.566^{* * *} \\
(0.181)\end{array}$ & & \\
\hline$\Delta \mathrm{m} \_$dollar & & & & $\begin{array}{c}0.683 * * \\
(0.326)\end{array}$ & $\begin{array}{c}0.938 * * \\
(0.380)\end{array}$ & & \\
\hline$\Delta \mathrm{m} \_$avg & & & & & & $\begin{array}{c}0.947 * * * \\
(0.090)\end{array}$ & $\begin{array}{c}0.899^{* * *} \\
(0.102)\end{array}$ \\
\hline$\Delta \operatorname{lgdp} \_a v g$ & & & & & & $\begin{array}{c}-1.431 * * \\
(0.673)\end{array}$ & $\begin{array}{c}-1.526^{* *} \\
(0.690)\end{array}$ \\
\hline constant & $\begin{array}{c}-0.040 * * \\
(0.016)\end{array}$ & $\begin{array}{c}-0.036^{* *} \\
(0.017)\end{array}$ & $\begin{array}{l}-0.019 \\
(0.019)\end{array}$ & $\begin{array}{l}-0.025 \\
(0.063)\end{array}$ & $\begin{array}{c}0.055 \\
(0.092)\end{array}$ & $\begin{array}{c}-0.018 \\
(0.030)\end{array}$ & $\begin{array}{c}-0.027 \\
(0.031) \\
\end{array}$ \\
\hline Observations & 2987 & 2056 & 2056 & 1076 & 1076 & 105 & 103 \\
\hline R-squared & 0.81 & 0.80 & 0.83 & 0.85 & 0.87 & 0.83 & 0.83 \\
\hline
\end{tabular}

Selected Summary Statistics

\begin{tabular}{lccccc}
\hline \multicolumn{1}{c}{ Variable } & Obs & Mean & Std. Dev. & Min & Max \\
\hline dlcpi & 2056 & 0.167 & 0.357 & -0.103 & 5.475 \\
dollar_avg & 2056 & 0.173 & 0.180 & 0.001 & 0.915 \\
dlm2_dollar_avg & 2056 & 0.052 & 0.156 & -0.514 & 2.591 \\
dollar & 1076 & 0.215 & 0.226 & 0.000 & 0.941 \\
dlm2_dollar & 1076 & 0.070 & 0.190 & -0.406 & 2.538 \\
\hline
\end{tabular}


Table 3. Dollarization and financial fragility

Dependent variable: First crisis year dummy

\begin{tabular}{|c|c|c|c|c|c|}
\hline & $\begin{array}{c}\text { Logit } \\
(1)\end{array}$ & $\begin{array}{l}\text { Logit } \\
(2)\end{array}$ & $\begin{array}{l}\text { Logit } \\
(3)\end{array}$ & $\begin{array}{c}\text { Logit } \\
(4)\end{array}$ & $\begin{array}{c}\text { Logit } \\
(5)\end{array}$ \\
\hline$\Delta \mathrm{p}$ & $\begin{array}{c}0.553 * * * \\
(0.201)\end{array}$ & $\begin{array}{l}-0.841 \\
(0.716)\end{array}$ & $\begin{array}{l}-1.673 \\
(1.089)\end{array}$ & & \\
\hline$\Delta \mathrm{tt}$ & $\begin{array}{l}-0.000 \\
(0.008)\end{array}$ & $\begin{array}{c}0.011 \\
(0.012)\end{array}$ & $\begin{array}{c}0.013 \\
(0.012)\end{array}$ & & \\
\hline real interest rate & $\begin{array}{c}-0.000 * * * \\
(0.000)\end{array}$ & $\begin{array}{c}-0.000 * * * \\
(0.000)\end{array}$ & $\begin{array}{l}-0.000 \\
(0.000)\end{array}$ & & \\
\hline M2/reserves & $\begin{array}{c}-0.010 \\
(0.008)\end{array}$ & $\begin{array}{l}-0.004 \\
(0.011)\end{array}$ & $\begin{array}{l}-0.005 \\
(0.011)\end{array}$ & & \\
\hline privcred/gdp & $\begin{array}{c}0.027 \\
(0.657)\end{array}$ & $\begin{array}{l}-0.597 \\
(1.142)\end{array}$ & $\begin{array}{l}-0.802 \\
(1.168)\end{array}$ & & \\
\hline cash/assets & $\begin{array}{l}-0.530 \\
(0.692)\end{array}$ & $\begin{array}{l}-0.568 \\
(0.963)\end{array}$ & $\begin{array}{l}-0.588 \\
(0.884)\end{array}$ & & \\
\hline capital flows/gdp & $\begin{array}{l}-1.114 \\
(1.017)\end{array}$ & $\begin{array}{l}-1.062 \\
(1.422)\end{array}$ & $\begin{array}{l}-1.651 \\
(1.429)\end{array}$ & & \\
\hline real gdp growth & $\begin{array}{l}-0.014 \\
(0.019)\end{array}$ & $\begin{array}{l}-0.000 \\
(0.033)\end{array}$ & $\begin{array}{l}-0.006 \\
(0.033)\end{array}$ & $\begin{array}{c}-0.041^{*} \\
(0.024)\end{array}$ & $\begin{array}{c}-0.047^{*} \\
(0.025)\end{array}$ \\
\hline real per capita gdp & $\begin{array}{c}0.000^{* *} \\
(0.000)\end{array}$ & $\begin{array}{l}0.000^{*} \\
(0.000)\end{array}$ & $\begin{array}{c}0.000^{* *} \\
(0.000)\end{array}$ & $\begin{array}{c}0.000 * * * \\
(0.000)\end{array}$ & $\begin{array}{c}0.000 * * * \\
(0.000)\end{array}$ \\
\hline$\Delta \mathrm{er}$ & & $\begin{array}{c}1.113 \\
(0.679)\end{array}$ & $\begin{array}{l}-0.895 \\
(1.326)\end{array}$ & $\begin{array}{c}0.489 * * * \\
(0.184)\end{array}$ & $\begin{array}{l}-1.309 \\
(1.004)\end{array}$ \\
\hline $\mathrm{FL} / \mathrm{FA}$ & & $\begin{array}{c}0.000 * * * \\
(0.000)\end{array}$ & $\begin{array}{c}0.005^{* *} \\
(0.003)\end{array}$ & $\begin{array}{c}0.000^{* * * *} \\
(0.000)\end{array}$ & $\begin{array}{c}0.004 * * \\
(0.002)\end{array}$ \\
\hline dollar_10 & & $\begin{array}{c}0.852^{* *} \\
(0.369)\end{array}$ & $\begin{array}{l}0.683^{*} \\
(0.411)\end{array}$ & $\begin{array}{c}0.881 * * * \\
(0.340)\end{array}$ & $\begin{array}{c}0.787^{* *} \\
(0.357)\end{array}$ \\
\hline $\mathrm{FL} / \mathrm{FA} * \Delta \mathrm{er}$ & & & $\begin{array}{c}0.106^{* *} \\
(0.051)\end{array}$ & & $\begin{array}{c}0.075^{* *} \\
(0.034)\end{array}$ \\
\hline dollar_10* $\Delta \mathrm{er}$ & & & $\begin{array}{c}2.351^{* *} \\
(1.196)\end{array}$ & & $\begin{array}{c}1.653^{*} \\
(0.980)\end{array}$ \\
\hline constant & $\begin{array}{c}-2.696^{* * *} \\
(0.356) \\
\end{array}$ & $\begin{array}{c}-2.921 * * * \\
(0.551) \\
\end{array}$ & $\begin{array}{c}-2.606 * * * \\
(0.544)\end{array}$ & $\begin{array}{c}-3.624 * * * \\
(0.310)\end{array}$ & $\begin{array}{c}-3.523 * * * \\
(0.325)\end{array}$ \\
\hline Observations & 1429 & 535 & 535 & 1041 & 1041 \\
\hline $\begin{array}{l}\Delta \mathrm{er}+\mathrm{FL} / \mathrm{FA}^{*} \Delta \mathrm{er}+\text { dollar_} 10 * \Delta \mathrm{er} \\
\text { (p-value) }\end{array}$ & & & $\begin{array}{c}1.660 \\
(0.175)\end{array}$ & & $\begin{array}{c}0.880 \\
(0.326)\end{array}$ \\
\hline $\begin{array}{l}\text { dollar_10+ dollar_10* }{ }^{*} \text { er } \\
\text { (p-value) }\end{array}$ & & & $\begin{array}{c}1.099^{* * *} \\
(0.005)\end{array}$ & & $\begin{array}{c}1.030^{* * *} \\
(0.004)\end{array}$ \\
\hline $\begin{array}{l}\text { FL/FA + FL/FA_ } \begin{array}{l}\text { er } \\
(\mathrm{p}-\mathrm{value})\end{array}\end{array}$ & & & $\begin{array}{l}0.024 * * \\
(0.039)\end{array}$ & & $\begin{array}{l}0.015^{* *} \\
(0.024)\end{array}$ \\
\hline
\end{tabular}

Notes: All regressors lagged one period. The crisis dummy equals one for the first year of a banking crisis.

Subsequent crisis years dropped from the sample. dollar_10 equals one if onshore deposit dollarization ratio exceeds $10 \%$. Robust standard errors in parentheses.

* significant at $10 \% ; * *$ significant at $5 \% ; * * *$ significant at $1 \%$

\section{Selected Summary Statistics}

\begin{tabular}{lccccc}
\hline \multicolumn{1}{c}{ Variable } & Obs & Mean & Std. Dev. & Min & Max \\
\hline Ser & 535 & .177011 & .4827931 & -.1407392 & 5.15798 \\
LF/LA & 535 & 25.56345 & 401.1965 & .0072505 & 8086.207 \\
dollar_10 & 535 & .4785047 & .5000053 & 0 & 1 \\
\hline
\end{tabular}


Table 4a. Dollarization and growth: Mean tests

\begin{tabular}{cccc}
\hline & $\begin{array}{c}\text { Low dollarization } \\
(\text { std dev. })\end{array}$ & $\begin{array}{c}\text { High dollarization } \\
\text { (std dev. })\end{array}$ & $\begin{array}{c}\text { Means-tests } \\
(p \text {-value })\end{array}$ \\
\hline Mean $(\Delta$ gdp_avg) & 0.035 & 0.026 & -0.010 \\
Mean $(\Delta$ gdp_sd) & $(0.015)$ & $(0.019)$ & $(0.000)$ \\
& 0.042 & 0.065 & 0.023 \\
\hline Number of countries & $(0.023)$ & $(0.043)$ & $(0.000)$ \\
\hline
\end{tabular}

Note: Low (high) dollarization countries are those with average dollarization ratios below (above) the sample median $($ median $=20 \%)$.

Table 4b. Dollarization and growth: Correlations

\begin{tabular}{c|cc} 
& $\begin{array}{c}\Delta \text { gdp_avg } \\
\text { (p-value) }\end{array}$ & $\Delta$ gdp_sd \\
\hline \multirow{3}{*}{ dollar_avg } & -0.2700 & 0.3814 \\
& $(0.0024)$ & $(0.0000)$ \\
& -0.2276 & \\
& $(0.0026)$ &
\end{tabular}

Note: The sample includes 124 countries. 
Table 5. Growth regressions

Dependent Variable: $\Delta$ gdp_avg

\begin{tabular}{|c|c|c|c|c|c|c|}
\hline & OLS & OLS & OLS & OLS & IV (i) & \multirow{3}{*}{$\begin{array}{c}\text { IV (i) } \\
\text { exc. offshore } \\
\text { (6) }\end{array}$} \\
\hline & \multirow[b]{2}{*}{ (1) } & \multirow[b]{2}{*}{ (2) } & \multicolumn{3}{|c|}{ exc. offshore } & \\
\hline & & & (3) & (4) & (5) & \\
\hline \multirow[t]{2}{*}{ Initial gdppc } & $-0.004 * *$ & $-0.005 * * *$ & $-0.005 * * *$ & $-0.005^{* * *}$ & $-0.006 * * *$ & $-0.006^{* * *}$ \\
\hline & $(0.001)$ & $(0.001)$ & $(0.001)$ & $(0.001)$ & $(0.001)$ & $(0.001)$ \\
\hline \multirow[t]{2}{*}{$\sec$} & 0.009 & $0.014^{*}$ & 0.001 & 0.003 & 0.010 & 0.012 \\
\hline & $(0.008)$ & $(0.008)$ & $(0.011)$ & $(0.011)$ & $(0.015)$ & $(0.016)$ \\
\hline \multirow[t]{2}{*}{ dollar_avg } & -0.014 & $-0.022 *$ & -0.015 & $-0.021 * *$ & $-0.054 * * *$ & $-0.064 * * *$ \\
\hline & $(0.011)$ & $(0.011)$ & $(0.010)$ & $(0.010)$ & $(0.018)$ & $(0.020)$ \\
\hline \multirow[t]{2}{*}{ invgdp_avg } & & $0.201 * * *$ & $0.170 * * *$ & $0.162 * * *$ & $0.169 * * *$ & $0.157 * * *$ \\
\hline & & $(0.040)$ & $(0.039)$ & $(0.039)$ & $(0.044)$ & $(0.046)$ \\
\hline \multirow[t]{2}{*}{ popg_avg } & & $0.380 * * *$ & $0.300 * *$ & $0.326^{* *}$ & $0.514 * * *$ & $0.543 * * *$ \\
\hline & & $(0.120)$ & $(0.130)$ & $(0.129)$ & $(0.180)$ & $(0.186)$ \\
\hline \multirow[t]{2}{*}{ latam } & & & $-0.009 * *$ & $-0.008^{*}$ & -0.004 & -0.002 \\
\hline & & & $(0.004)$ & $(0.004)$ & $(0.006)$ & $(0.006)$ \\
\hline \multirow[t]{2}{*}{ transition } & & & $-0.013 * * *$ & $-0.011 * *$ & -0.006 & -0.003 \\
\hline & & & $(0.005)$ & $(0.004)$ & $(0.007)$ & $(0.007)$ \\
\hline \multirow[t]{2}{*}{ safrica } & & & $-0.015 * *$ & $-0.014 * *$ & -0.011 & -0.009 \\
\hline & & & $(0.006)$ & $(0.006)$ & $(0.007)$ & $(0.007)$ \\
\hline \multirow[t]{2}{*}{ constant } & $0.036 * * *$ & -0.014 & 0.005 & 0.005 & 0.002 & 0.003 \\
\hline & $(0.004)$ & $(0.009)$ & $(0.010)$ & $(0.010)$ & $(0.011)$ & $(0.011)$ \\
\hline Observations & 77 & 67 & 67 & 65 & 65 & 63 \\
\hline R-squared & 0.09 & 0.53 & 0.60 & 0.59 & 0.48 & 0.47 \\
\hline
\end{tabular}

Robust standard errors in parentheses

* significant at $10 \%$; * significant at 5\%; *** significant at $1 \%$.

(i) Instruments: gdppc74, sec, inggdp_avg, popg_avg, latam, transition, safrica, and restrictions.

Selected Summary Statistics

\begin{tabular}{lccccc}
\hline \multicolumn{1}{c}{ Variable } & Obs & Mean & Std. Dev. & Min & Max \\
\hline Igdp_avg & 77 & 0.033 & 0.017 & -0.017 & 0.081 \\
Initial gdppc & 77 & 1.260 & 1.648 & 0.019 & 9.828 \\
dollar_avg & 77 & 0.173 & 0.167 & 0.001 & 0.756 \\
invgdp_avg & 67 & 0.213 & 0.050 & 0.097 & 0.316 \\
popg_avg & 67 & 0.020 & 0.014 & -0.000 & 0.087 \\
\hline
\end{tabular}


Table 6. Output volatility regressions

Dependent Variable: $\Delta \mathrm{gdp} \_s d$

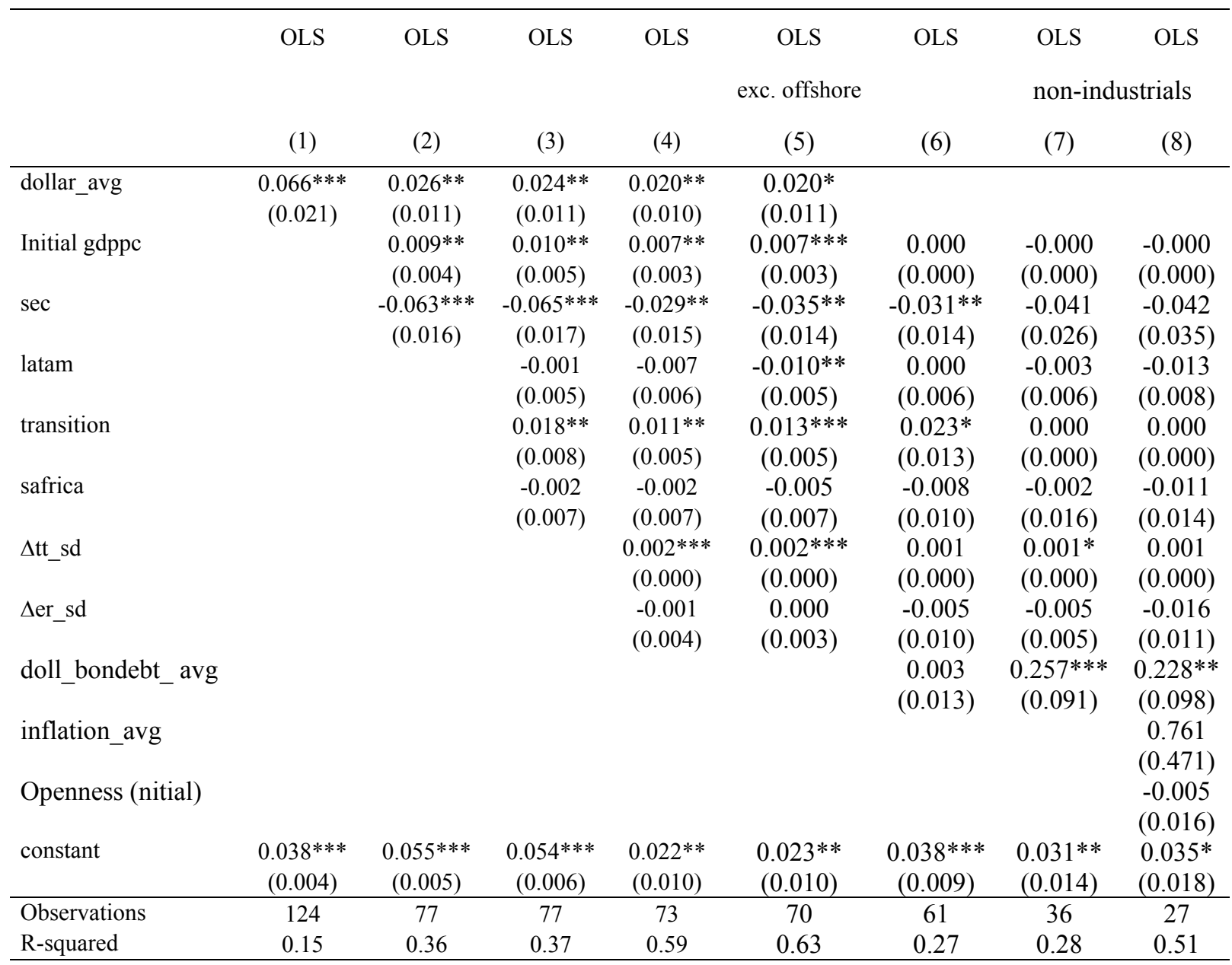

Robust standard errors in parentheses

$*$ significant at $10 \%$;* significant at $5 \%$; ** significant at $1 \%$.

Selected Summary Statistics

\begin{tabular}{lccccc}
\hline \multicolumn{1}{c}{ Variable } & Obs & Mean & Std. Dev. & Min & Max \\
\hline Sgdp_sd & 124 & 0.053 & 0.036 & 0.015 & 0.264 \\
dollar_avg & 124 & 0.234 & 0.209 & 0.001 & 0.915 \\
Initial gdppc & 77 & 1.291 & 1.682 & 0.019 & 9.828 \\
sec & 77 & 0.412 & 0.272 & 0.010 & 0.910 \\
doll_bondebt_avg & 61 & 0.120 & 0.188 & 0.000 & 1.260 \\
\hline
\end{tabular}


Figure 1. Deposit and loan dollarization

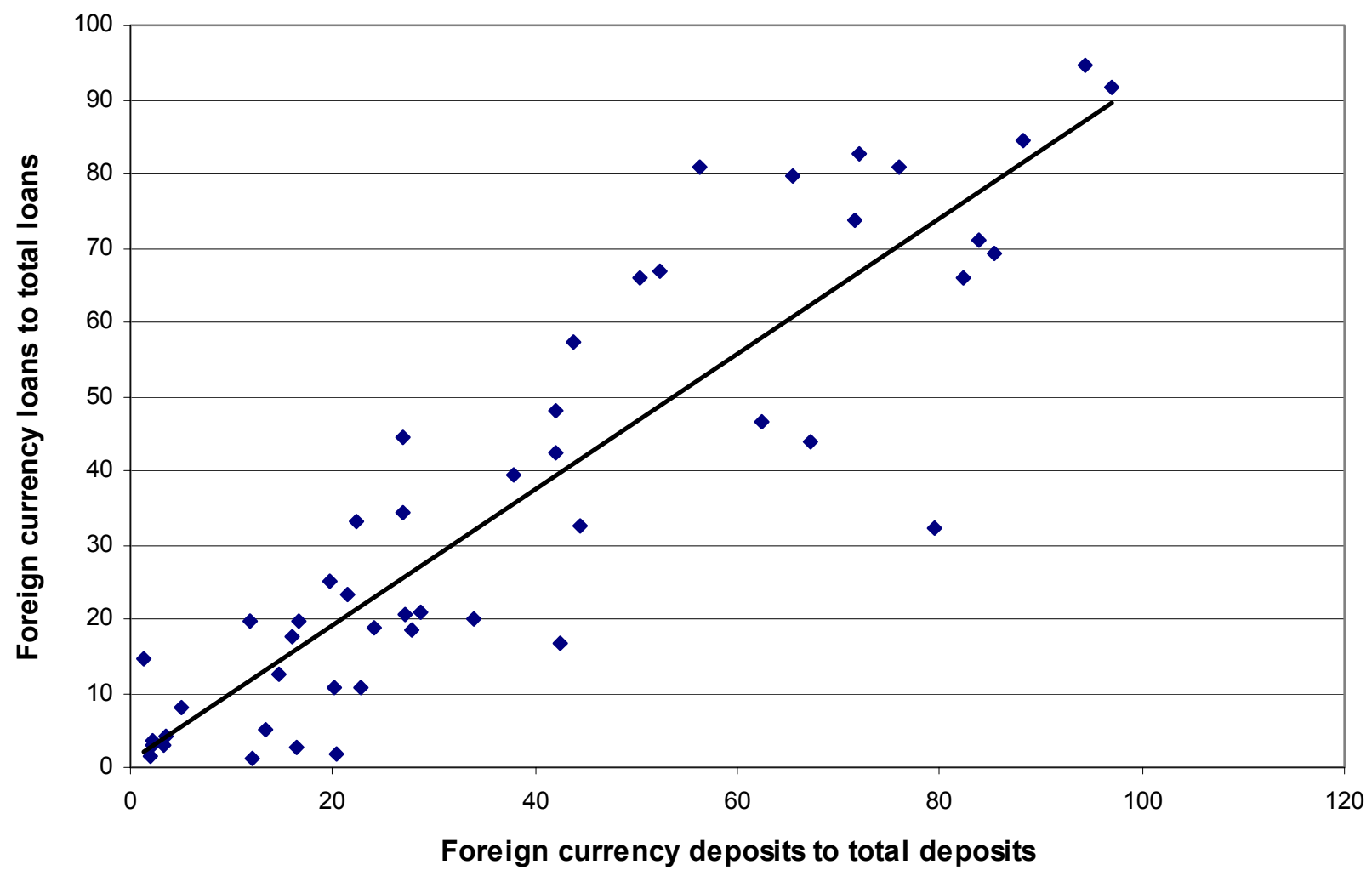

Note: Foreign currency loans sourced from De Nicoló et al. (2003) and Arteta (2002). 
Figure 2. Financial dollarization and financial depth (average ratios)

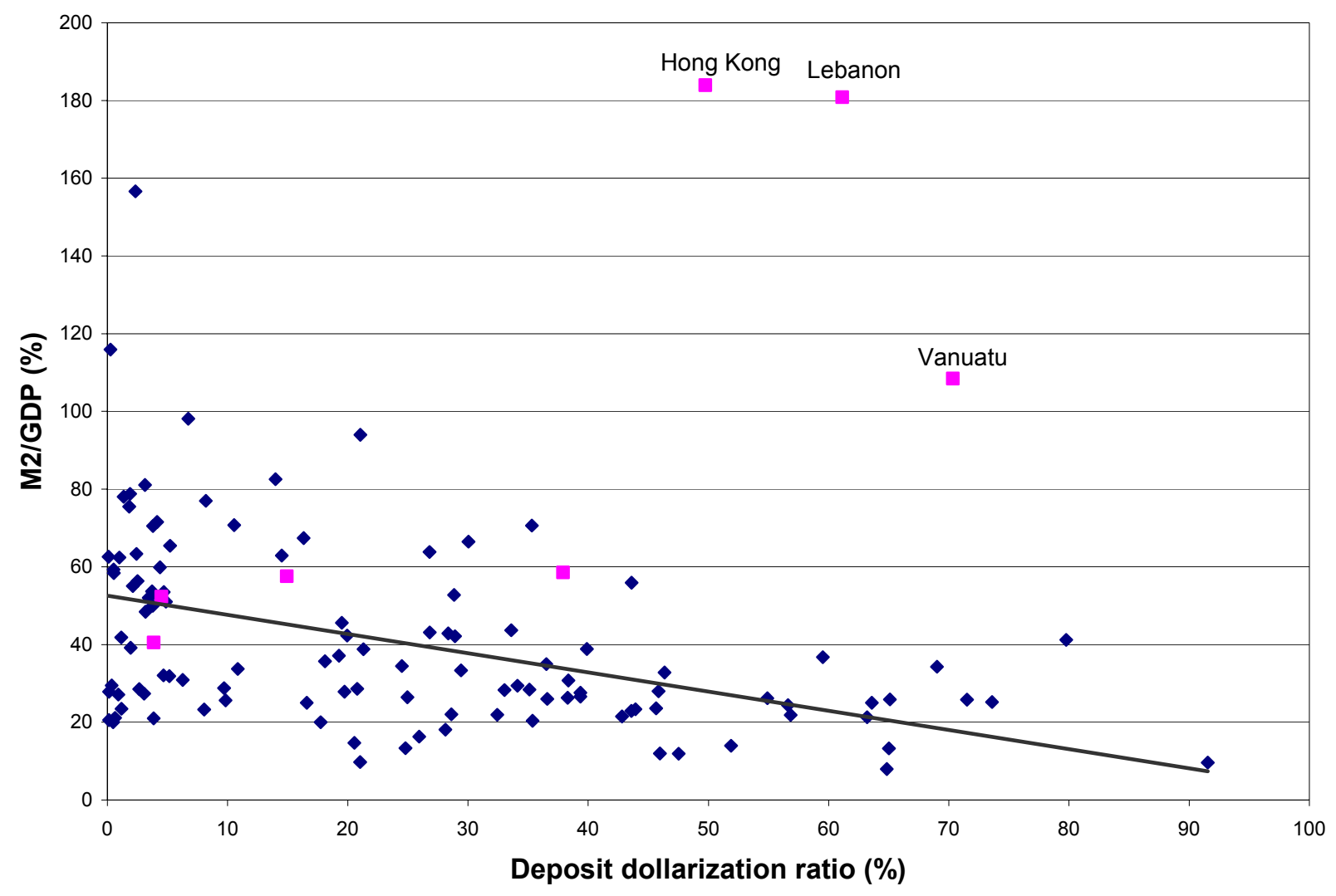

Notes: Square markers represent offshore countries. The trendline represents the locus of the fitted values of a simple regression of the average M2-to-GDP ratio on the average deposit dollarization ratio, excluding offshore observations. The regression cofficient is -0.005 with a t-statistic of -5.27 . 


\section{Appendix}

Table A1. Variable definitions and sources

\begin{tabular}{|c|c|}
\hline Variable & Definitions (sources) \\
\hline$\Delta \mathrm{p}$ & Logarithmic difference of the CPI. (IMF’s World Economic Outlook [WEO]) \\
\hline$\Delta \mathrm{e}$ & $\begin{array}{l}\text { Logarithmic difference of the nominal exchange rate (IMF's World Economic Outlook } \\
\text { [WEO]). }\end{array}$ \\
\hline restrictions & $\begin{array}{l}\text { Index of restrictiveness of rules on resident holdings of foreign currency deposits } \\
\text { onshore, revised and expanded from De Nicoló et al. (2003), using their methodology. }\end{array}$ \\
\hline sec & $\begin{array}{l}\text { School enrollment, secondary (\% gross) (IBRD's World Development Indicators } \\
\text { [WDI]). }\end{array}$ \\
\hline$\Delta \mathrm{m}$ & Logarithmic difference of M2 (IFS). \\
\hline$\Delta \mathrm{gdp}$ & Logarithmic difference of real GDP (IFS). \\
\hline crisis & Dummy variable equal to one for the first crisis year (Caprio and Klingebiel, 2003). \\
\hline real gdp growth & Percent variation of GDP in local currency at constant prices (WDI). \\
\hline $\begin{array}{l}\text { real per capita } \\
\text { gdp }\end{array}$ & GDP per capita, constant prices in local currency (WEO). \\
\hline M2 / GDP & Ratio of M2 over GDP (IFS). \\
\hline M2 / reserves & Ratio of M2 over international reserves (IFS). \\
\hline Cash/assets & Reserves of deposit money banks over assets of deposit money banks (IFS) \\
\hline privcred/GDP & Bank credit to the resident private sector over GDP (IFS) \\
\hline gdppc_us & GDP per capita denominated in US dollars (WEO). \\
\hline intrate & Nominal interest rate (IFS). \\
\hline $\begin{array}{l}\text { dollar } \\
\text { openness }\end{array}$ & $\begin{array}{l}\text { Dollar deposits over total deposits in local deposit money banks (various sources). } \\
\text { (Export + Import) / GDP (IFS). }\end{array}$ \\
\hline$\Delta \mathrm{tt}$ & $\begin{array}{l}\text { Logarithmic difference of terms of trade (WDI: exports as a cpacity to import (constant } \\
\text { LCU)). }\end{array}$ \\
\hline $\begin{array}{l}\text { private } \\
\text { credit/gdp }\end{array}$ & Credit growth/GDP (IFS). \\
\hline cash / assets & Reserves of deposit money banks / assets of deposits money (IFS). \\
\hline FL/FA & Deposit money banks' foreign liabilities over foreign assets (IFS). \\
\hline $\begin{array}{l}\text { capital } \\
\text { flows/gdp }\end{array}$ & Capital account + financial account + net errors and omissions (IFS). \\
\hline latam & Dummy variable for Latin American countries. \\
\hline transition & Dummy variable for transition countries. \\
\hline safrica & Dummy variable for Sub-Saharan African countries. \\
\hline offshore & Dummy variable for offshore centers (BIS). \\
\hline
\end{tabular}


Table A2. Onshore deposit dollarization data: Countries and periods covered

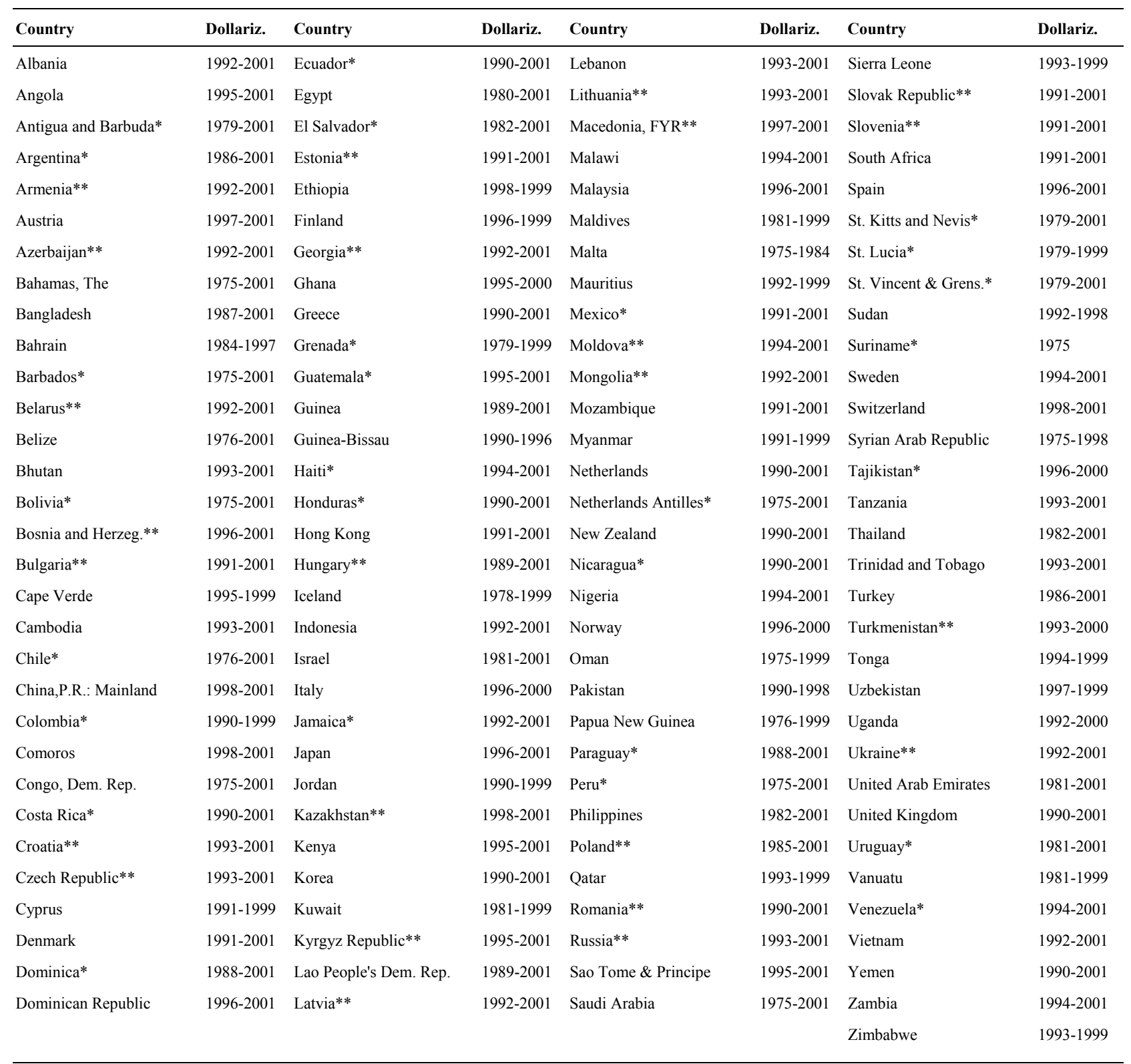

Note: $(*)$ denotes Latin American countries and $(* *)$ denotes Transition countries. 
Table A3. Cross-border loans: Countries and periods covered

\begin{tabular}{|c|c|c|c|c|c|}
\hline Country & $\begin{array}{c}\text { Period } \\
\text { covered }\end{array}$ & Country & $\begin{array}{c}\text { Period } \\
\text { covered }\end{array}$ & Country & $\begin{array}{c}\text { Period } \\
\text { covered }\end{array}$ \\
\hline Afghanistan & $1995-2000$ & Ghana & $1995-2002$ & Nigeria & $1995-2002$ \\
\hline Albania** & $1995-2002$ & Greece & $1995-2002$ & Norway & $1995-2002$ \\
\hline Algeria & $1995-2002$ & Grenada* & $1995-2002$ & Oman & 1995-2002 \\
\hline Angola & $1995-2002$ & Guatemala* & $1995-2002$ & Pakistan & $1995-2002$ \\
\hline Argentina* & $1995-2002$ & Guinea & $1995-2002$ & Panama* & 1995-2002 \\
\hline Aruba* & $1995-2002$ & Guinea-Bissau & $1995-2002$ & Papua New Guinea & $1995-2002$ \\
\hline Armenia** & $1995-2002$ & Guyana* & $1995-2002$ & Paraguay* & $1995-2002$ \\
\hline Australia & $1995-2002$ & Haiti* & $1995-2002$ & Peru* & 1995-2002 \\
\hline Austria & $1995-2002$ & Honduras* & $1995-2002$ & Philippines & $1995-2002$ \\
\hline Azerbaijan** & $1995-2002$ & Hong Kong & $1995-2002$ & Poland** & $1995-2002$ \\
\hline Bahamas, The* & $1995-2002$ & Hungary** & $1995-2002$ & Portugal & $1995-2002$ \\
\hline Bahrain & $1995-2002$ & Iceland & $1995-2002$ & Qatar & 1995-2002 \\
\hline Bangladesh & $1995-2002$ & India & $1995-2002$ & Romania** & $1995-2002$ \\
\hline Barbados* & $1995-2002$ & Indonesia & $1995-2002$ & Russia** & $1995-2002$ \\
\hline Belarus** & $1995-2002$ & Iran, I.R. of & $1995-2002$ & Rwanda & $1995-2002$ \\
\hline Belize* & $1995-2002$ & Iraq & $1995-2000$ & Saudi Arabia & 1995-2002 \\
\hline Benin & $1995-2002$ & Ireland & $1995-2002$ & Sao Tome \& Principe & 1995-2002 \\
\hline Bhutan & $1995-2002$ & Israel & $1995-2002$ & Senegal & 1995-2002 \\
\hline Bolivia* & $1995-2002$ & Italy & $1995-2002$ & Seychelles & 1995-2002 \\
\hline Bosnia and Herzegovina** & $1995-2002$ & Jamaica* & $1995-2002$ & Sierra Leone & 1995-2002 \\
\hline Botswana & $1995-2002$ & Japan & $1995-2002$ & Singapore & 1995-2002 \\
\hline Brazil* & $1995-2002$ & Jordan & $1995-2002$ & Slovak Republic** & 1995-2002 \\
\hline Bulgaria** & $1995-2002$ & Kazakhstan** & $1995-2002$ & Solomon Islands & 1995-2002 \\
\hline Burkina Faso & $1995-2002$ & Kenya & $1995-2002$ & Somalia & $1995-2002$ \\
\hline Burundi & $1995-2002$ & Kiribati & $1995-2002$ & South Africa & 1995-2002 \\
\hline Cambodia & $1995-2002$ & Kuwait & $1995-2002$ & Spain & 1995-2002 \\
\hline Cameroon & $1995-2002$ & Kyrgyz Republic** & $1995-2002$ & Sri Lanka & 1995-2002 \\
\hline Cape Verde & $1995-2002$ & Lao People's Dem. Rep & $1995-2002$ & St. Lucia* & $1995-2002$ \\
\hline Central African Republic & $1995-2002$ & Latvia** & $1995-2002$ & St. Vincent \& Grens.* & 1995-2002 \\
\hline Chad & $1995-2002$ & Lebanon & $1995-2002$ & Sudan & 1995-2002 \\
\hline Chile* & $1995-2002$ & Lesotho & $1995-2002$ & Swaziland & 1995-2002 \\
\hline China: Mainland & $1995-2002$ & Liberia & $1995-2002$ & Sweden & 1995-2002 \\
\hline Colombia* & $1995-2002$ & Libya & $1995-2002$ & Switzerland & 1995-2002 \\
\hline Comoros & $1995-2002$ & Lithuania** & $1995-2002$ & Syrian Arab Republic & $1995-2002$ \\
\hline Congo, Dem. Rep. & $1995-2002$ & Luxembourg & $1995-2002$ & Tajikistan $* *$ & 1995-2002 \\
\hline Congo, Republic of & $1995-2002$ & Macedonia, FYR** & $1995-2002$ & Tanzania & $1995-2002$ \\
\hline Costa Rica* & $1995-2002$ & Madagascar & $1995-2002$ & Thailand & 1995-2002 \\
\hline Cote D'Ivoire & $1995-2002$ & Malawi & $1995-2002$ & Togo & 1995-2002 \\
\hline Croatia** & $1995-2002$ & Malaysia & $1995-2002$ & Tonga & 1995-2002 \\
\hline Cyprus & $1995-2002$ & Maldives & $1995-2002$ & Trinidad \& Tobago* & 1995-2002 \\
\hline Czech Republic** & $1995-2002$ & Mali & $1995-2002$ & Tunisia & 1995-2002 \\
\hline Djibouti & $1995-2002$ & Malta & $1995-2002$ & Turkey & $1995-2002$ \\
\hline Dominica* & $1995-2002$ & Mauritania & $1995-2002$ & Turkmenistán** & 1995-2002 \\
\hline Dominican Republic* & $1995-2002$ & Mauritius & $1995-2002$ & Uganda & 1995-2002 \\
\hline Ecuador* & $1995-2002$ & Mexico* & $1995-2002$ & Ukraine** & 1995-2002 \\
\hline Egypt & $1995-2002$ & Moldova** & $1995-2002$ & United Arab Emirates & $1995-2002$ \\
\hline El Salvador* & $1995-2002$ & Mongolia** & $1995-2002$ & United Kingdom & 1995-2002 \\
\hline Equatorial Guinea & $1995-2002$ & Morocco & $1995-2002$ & United States & $1995-2002$ \\
\hline Estonia** & $1995-2002$ & Mozambique & $1995-2002$ & Uruguay* & 1995-2002 \\
\hline Ethiopia & $1995-2002$ & Myanmar & $1995-2002$ & Uzbekistán** & 1995-2002 \\
\hline Fiji & $1995-2002$ & Namibia & $1995-2002$ & Vanuatu & 1995-2002 \\
\hline Finland & $1995-2002$ & Nepal & $1995-2002$ & Venezuela* & 1995-2002 \\
\hline France & $1995-2002$ & Netherlands & $1995-2002$ & Vietnam & 1995-2002 \\
\hline Gabon & $1995-2002$ & Netherlands Antilles & $1995-2002$ & Yemen & 1995-2002 \\
\hline Gambia, The & $1995-2002$ & New Zealand & $1995-2002$ & Zambia & 1995-2002 \\
\hline Georgia** & $1995-2002$ & Nicaragua* & $1995-2002$ & Zimbabwe & 1995-2002 \\
\hline Germany & $1995-2002$ & Niger & $1995-2002$ & & \\
\hline
\end{tabular}

Note: $(*)$ denotes Latin American countries and (**) denotes Transition countries. Source: BIS. 
Table A4. External debt data: Countries and periods covered

\begin{tabular}{|c|c|c|c|}
\hline Country & Period covered & Country & Period covered \\
\hline Algeria & 1993-1994 & Korea & $1993-2001$ \\
\hline Argentina* & $1993-2001$ & Latvia** & $1997-2001$ \\
\hline Aruba (1) & $1994-2001$ & Lebanon & $1995-2001$ \\
\hline Australia & $1993-2001$ & Liberia (1) & $1997-2000$ \\
\hline Austria & $1993-2001$ & Lithuania** & $1995-2001$ \\
\hline Bahrain & $1993-2001$ & Luxembourg & $1993-2001$ \\
\hline Barbados* & $1993-2000$ & Malaysia & $1993-2001$ \\
\hline Belgium & $1993-2001$ & Malta & $1994-2001$ \\
\hline Bolivia* & 1994 & Mauritius & $1995-2001$ \\
\hline Brazil* & $1993-2001$ & México* & $1993-2001$ \\
\hline Bulgaria** & $1993-2001$ & Moldova** & $1997-2001$ \\
\hline Canada & $1993-2001$ & Morocco & $1993-2001$ \\
\hline Chile* & $1993-2001$ & Netherlands & $1993-2001$ \\
\hline China: Mainland & $1990-2001$ & Netherlands Ant.* & $1993-2001$ \\
\hline China:Hong Kong & $1993-2001$ & New Zealand & $1993-2001$ \\
\hline Colombia* & $1993-2001$ & Nicaragua* & $1993-2001$ \\
\hline Costa Rica* & $1993-2001$ & Norway & $1993-2001$ \\
\hline Croatia** & $1997-2001$ & Oman & $1993-2001$ \\
\hline Cyprus & $1993-2001$ & Pakistan & $1993-2001$ \\
\hline Czech Republic** & $1993-2001$ & Panama* & $1993-2001$ \\
\hline Denmark & $1993-2001$ & Papua New Guinea & 1994-1999 \\
\hline Dominican Rep.* & $1997-2001$ & Peru* & $1994-2001$ \\
\hline Ecuador* & $1993-2001$ & Philippines & $1993-2001$ \\
\hline Egypt & 2001 & Poland** & $1994-2001$ \\
\hline Estonia** & $1996-2001$ & Portugal & $1993-2001$ \\
\hline Finland & $1993-2001$ & Qatar & $1996-2001$ \\
\hline France & $1993-2001$ & Romania** & $1993-2001$ \\
\hline Germany & $1993-2001$ & Russia** & $1993-2001$ \\
\hline Greece & $1993-2001$ & Singapore & $1993-2001$ \\
\hline Guatemala* & $1993-2001$ & Slovak Republic** & 1994-2001 \\
\hline Haití* & 1993-1994 & Slovenia** & $1997-2001$ \\
\hline Hungary** & $1993-2001$ & South Africa & $1993-2001$ \\
\hline Iceland & $1993-2001$ & Spain & $1993-2001$ \\
\hline India & $1993-2001$ & Sri Lanka & $1997-2001$ \\
\hline Indonesia & $1993-2001$ & Sweden & $1993-2001$ \\
\hline Ireland & $1993-2001$ & Switzerland & $1993-2001$ \\
\hline Israel & $1993-2001$ & Thailand & $1993-2001$ \\
\hline Italy & $1993-2001$ & Tunisia & $1993-2001$ \\
\hline Jamaica* & $1996-2001$ & Turkey & $1993-2001$ \\
\hline Japan & $1993-2001$ & United Kingdom & $1993-2001$ \\
\hline Jordan & $1993-2001$ & United States & $1993-2001$ \\
\hline Kazakhstan** & $1996-2001$ & Uruguay* & $1993-2001$ \\
\hline \multirow[t]{2}{*}{ Kenya } & 1997 & Venezuela* & $1993-2001$ \\
\hline & & Zimbabwe & 1994 \\
\hline
\end{tabular}

Notes: (*) denotes Latin American countries and $(* *)$ denotes Transition countries.

Source: BIS.

(1) Countries without GDP data, thus not included in the sample. 
Table A5. Long-term debt with official creditors: Countries and periods covered

\begin{tabular}{|c|c|c|c|c|c|}
\hline Country & $\begin{array}{c}\text { Period } \\
\text { covered }\end{array}$ & Country & $\begin{array}{c}\text { Period } \\
\text { covered }\end{array}$ & Country & $\begin{array}{c}\text { Period } \\
\text { covered }\end{array}$ \\
\hline Albania** & $1990-2000$ & Guinea-Bissau & $1970-2000$ & Sao Tome \& Principe & $1971-2000$ \\
\hline Algeria & $1970-2000$ & Guyana* & $1970-2000$ & Senegal & $1970-2000$ \\
\hline Angola & $1981-2000$ & Haiti* & $1970-2000$ & Seychelles & $1971-2000$ \\
\hline Argentina* & $1970-2000$ & Honduras* & $1970-2000$ & Sierra Leone & $1970-2000$ \\
\hline Armenia** & $1993-2000$ & Hungary** & $1971-2000$ & Slovak Republic** & $1981-2000$ \\
\hline Azerbaijan** & $1993-2000$ & India & $1970-2000$ & Solomon Islands & $1971-2000$ \\
\hline Bangladesh & $1971-2000$ & Indonesia & $1970-2000$ & Somalia & $1970-2000$ \\
\hline Belarus** & $1993-2000$ & Iran, I.R. of & $1971-2000$ & South Africa & 1994-2000 \\
\hline Belize* & $1970-2000$ & Jamaica* & $1970-2000$ & Sri Lanka & $1970-2000$ \\
\hline Benin & $1970-2000$ & Jordan & $1970-2000$ & St. Kitts and Nevis* & $1981-2000$ \\
\hline Bhutan & $1981-2000$ & Kazakhstan** & $1992-2000$ & St. Lucia* & $1970-2000$ \\
\hline Bolivia* & $1970-2000$ & Kenya & $1970-2000$ & St. Vincent \& Grens.* & $1970-2000$ \\
\hline Bosnia and Herzegovina** & $1999-2000$ & Korea & $1970-2000$ & Sudan & $1970-2000$ \\
\hline Botswana & $1970-2000$ & Kyrgyz Republic** & $1970-2000$ & Swaziland & $1970-2000$ \\
\hline Brazil* & $1970-2000$ & Lao People's Dem. Rep & $1970-2000$ & Syrian Arab Republic & $1970-2000$ \\
\hline Bulgaria** & $1981-2000$ & Latvia** & $1992-2000$ & Tajikistan** & $1992-2000$ \\
\hline Burkina Faso & $1970-2000$ & Lebanon & $1970-2000$ & Tanzania & $1970-2000$ \\
\hline Burundi & $1970-2000$ & Lesotho & $1970-2000$ & Thailand & $1970-2000$ \\
\hline Cambodia & $1981-2000$ & Liberia & $1970-2000$ & Togo & $1970-2000$ \\
\hline Cameroon & $1970-2000$ & Lithuania** & $1992-2000$ & Tonga & $1981-2000$ \\
\hline Cape Verde & $1981-2000$ & Macedonia, FYR** & $1993-2000$ & Trinidad \& Tobago* & $1970-2000$ \\
\hline Central African Republic & $1970-2000$ & Madagascar & $1970-2000$ & Tunisia & $1970-2000$ \\
\hline Chad & $1970-2000$ & Malawi & $1970-2000$ & Turkey & $1970-2000$ \\
\hline Chile* & $1970-2000$ & Malaysia & $1970-2000$ & Turkmenistán** & $1993-2000$ \\
\hline China: Mainland & $1981-2000$ & Maldives & $1971-2000$ & Uganda & $1970-2000$ \\
\hline Colombia* & $1970-2000$ & Mali & $1970-2000$ & Ukraine** & $1992-2000$ \\
\hline Comoros & $1970-2000$ & Mauritania & $1970-2000$ & Uruguay* & $1970-2000$ \\
\hline Congo, Dem. Rep. & $1970-2000$ & Mauritius & $1970-2000$ & Uzbekistán** & $1992-2000$ \\
\hline Congo, Republic of & $1970-2000$ & Mexico* & $1970-2000$ & Vanuatu & $1971-2000$ \\
\hline Costa Rica* & $1970-2000$ & Moldova** & $1992-2000$ & Venezuela* & $1970-2000$ \\
\hline Cote D'Ivoire & $1970-2000$ & Mongolia** & $1993-2000$ & Vietnam & $1981-2000$ \\
\hline Croatia** & $1993-2000$ & Morocco & $1970-2000$ & Yemen & $1971-2000$ \\
\hline Czech Republic** & $1981-2000$ & Mozambique & $1981-2000$ & Zambia & $1970-2000$ \\
\hline Djibouti & $1970-2000$ & Myanmar & $1970-2000$ & Zimbabwe & $1970-2000$ \\
\hline Dominica* & $1981-2000$ & Nepal & $1970-2000$ & & \\
\hline Dominican Republic* & $1970-2000$ & Nicaragua* & $1970-2000$ & & \\
\hline Ecuador* & $1970-2000$ & Niger & $1970-2000$ & & \\
\hline Egypt & $1970-2000$ & Nigeria & $1970-2000$ & & \\
\hline El Salvador* & $1970-2000$ & Oman & $1971-2000$ & & \\
\hline Equatorial Guinea & $1970-2000$ & Pakistan & $1970-2000$ & & \\
\hline Estonia** & $1992-2000$ & Panama* & $1970-2000$ & & \\
\hline Ethiopia & $1970-2000$ & Papua New Guinea & $1970-2000$ & & \\
\hline Fiji & $1970-2000$ & Paraguay* & $1970-2000$ & & \\
\hline Gabon & $1970-2000$ & Peru* & $1970-2000$ & & \\
\hline Gambia, The & $1970-2000$ & Philippines & $1970-2000$ & & \\
\hline Georgia** $^{* *}$ & $1992-2000$ & Poland** & $1981-2000$ & & \\
\hline Ghana & $1970-2000$ & Romania** & $1970-2000$ & & \\
\hline Grenada* & $1970-2000$ & Russia** & $1981-2000$ & & \\
\hline Guatemala* & $1970-2000$ & Rwanda & $1970-2000$ & & \\
\hline Guinea & $1970-2000$ & Samoa & $1970-2000$ & & \\
\hline
\end{tabular}

Note: $(*)$ denotes Latin American countries and $\left({ }^{* *}\right)$ denotes Transition countries. Source: Global Development Finance. 
Table A6. Index of restrictions on holdings of foreign currency deposits by residents (as of beginning of 2000)

\begin{tabular}{|c|c|c|c|c|c|c|c|c|c|}
\hline Country & Restrictions & Firms & Households & Prior approval & Country & Restrictions & Firms & Households & Prior approval \\
\hline Albania & 0 & . & . & . & Ghana & 0 & . & . & . \\
\hline Angola & 0 & . & . & . & Greece & 0 & . & . & . \\
\hline Antigua and Barb. & 2 & 1 & . & 1 & Grenada & 2 & 1 & 1 & . \\
\hline Argentina & 0 & . & . & . & Guatemala & 5 & 2 & 2 & 1 \\
\hline Armenia & 0 & . & . & . & Guinea & 0 & . & . & . \\
\hline Austria & 0 & . & . & . & Guinea-Bissau & 1 & . & . & 1 \\
\hline Azerbaijan & 0 & . & . & . & Haití & 1 & 1 & . & . \\
\hline Bahamas, The & 1 & . & . & 1 & Honduras & 0 & . & . & . \\
\hline Bahrain & 0 & . & . & . & Hungary & 1 & 1 & . & . \\
\hline Bangladesh & 3 & 1 & 1 & 1 & Iceland & 0 & . & . & . \\
\hline Barbados & 3 & 1 & 1 & 1 & Indonesia & 0 & . & . & . \\
\hline Belarus & 0 & . & . & . & Israel & 0 & . & . & . \\
\hline Belice & 1 & . & . & 1 & Italy & 0 & . & . & . \\
\hline Bhutan & 5 & 2 & 2 & 1 & Jamaica & 0 & . & . & . \\
\hline Bolivia & 0 & . & . & . & Japan & 0 & . & . & . \\
\hline Bosnia and Herzeg. & 0 & . & . & . & Jordan & 0 & . & . & . \\
\hline Brazil & 2 & 1 & 1 & . & Kazakhstan & 0 & . & . & . \\
\hline Bulgaria & 0 & . & . & . & Kenya & 0 & . & . & . \\
\hline Cambodia & 0 & . & . & . & Korea & 0 & . & . & . \\
\hline Cape Verde & 1 & . & . & 1 & Kuwait & 0 & . & . & . \\
\hline Chile & 0 & . & . & . & Kyrgyz Republic & 0 & . & . & . \\
\hline China: Mainland & 2 & 1 & . & 1 & Lao People's Dem. & 0 & . & . & . \\
\hline China: Hong Kong & 0 & . & . & . & Latvia & 0 & . & . & . \\
\hline Colombia & 3 & 1 & 2 & . & Lebanon & 0 & . & . & . \\
\hline Comoros & 1 & . & . & 1 & Lithuania & 0 & . & . & . \\
\hline Congo, Dem. Rep. & 0 & . & . & . & Macedonia, FYR & 0 & . & . & . \\
\hline Costa Rica & 0 & . & . & . & Malawi & 2 & 1 & 1 & . \\
\hline Croatia & 0 & . & . & . & Malaysia & 3 & . & 2 & 1 \\
\hline Cyprus & 3 & 1 & 1 & 1 & Maldives & 0 & . & . & . \\
\hline Czech Republic & 0 & . & . & . & Malta & 3 & 1 & 1 & 1 \\
\hline Denmark & 0 & . & . & . & Mauritius & 0 & . & . & . \\
\hline Dominica & 4 & 1 & 2 & 1 & México & 2 & 1 & 1 & . \\
\hline Ecuador & 0 & . & . & . & Moldova & 0 & . & . & . \\
\hline Egypt & 0 & . & . & . & Mongolia & 0 & . & . & . \\
\hline El Salvador & 0 & . & . & . & Mozambique & 0 & . & . & . \\
\hline Estonia & 0 & . & . & . & Myanmar & 3 & 1 & 1 & 1 \\
\hline Etiopía & 4 & 1 & 2 & 1 & Netherlands & 0 & . & . & . \\
\hline Finland & 0 & . & . & . & Netherlands Antilles & 0 & . & . & . \\
\hline Georgia & 0 & . & . & . & New Zealand & 0 & . & . & . \\
\hline
\end{tabular}


Table A6. Index of restrictions on holdings of foreign currency deposits by residents (as of beginning of 2000) (cont.)

\begin{tabular}{|c|c|c|c|c|c|c|c|c|c|}
\hline Nicaragua & 0 & . & . & . & Suriname & 0 & . & . & . \\
\hline Nigeria & 1 & . & . & 1 & Sweden & 0 & . & . & . \\
\hline Oman & 0 & . & . & . & Syrian Arab Rep. & 0 & . & . & . \\
\hline Papua New Guinea & 1 & 1 & . & . & Tajikistan & 0 & . & . & . \\
\hline Paraguay & 0 & . & . & . & Tanzania & 0 & . & . & . \\
\hline Poland & 0 & . & . & . & Trinidad \& Tobago & 0 & . & . & . \\
\hline Qatar & 0 & . & . & . & Turkey & 0 & . & . & . \\
\hline Romania & 0 & . & . & . & Turkmenistán & 3 & 1 & 1 & 1 \\
\hline Russia & 0 & . & . & . & Uganda & 0 & . & . & . \\
\hline Rwanda & 3 & 1 & 1 & 1 & Ukraine & 1 & . & . & 1 \\
\hline Slovenia & 0 & . & . & . & Vanuatu & 0 & . & . & . \\
\hline South Africa & 0 & . & . & . & Venezuela & 0 & . & . & . \\
\hline Spain & 0 & . & . & . & Vietnam & 2 & 1 & 1 & . \\
\hline St. Kitts and Nevis & 3 & 1 & 1 & 1 & Yemen & 0 & . & . & . \\
\hline St. Lucia & 0 & . & . & . & Zambia & 0 & . & . & . \\
\hline St. Vincent \& G. & 0 & . & . & . & Zimbabwe & 0 & . & . & . \\
\hline Sudan & 0 & . & . & . & & & & & \\
\hline
\end{tabular}

Source: IMF, Annual Report on Exchange Arrangements and Exchange Restrictions 2001, based on De Nicoló et al. (2003).

Firms and Households equal 1 if only documented proceeds of exports or remittances can be lodged to the account;

2 if accounts are not permitted or are limited to a very narrow category of holder. Prior approval equals 1 if required.

Restrictions is computed as the sum of the remaining three columns. 